\title{
KVANTITATIVNA ANALIZA RJEČNIKA SPORTSKOGA NAZIVLJA
}

\author{
Darija Omrčen * \\ Kineziološki fakultet Sveučilišta u Zagrebu
}

\begin{abstract}
Terminološki rječnici nastoje prikupiti i organizirati nazivlje određenoga predmetnog područja. $S$ razvojem društva, znanosti i tehnologije raste $\mathrm{i}$ broj predmetnih područja, a time $\mathrm{i}$ broj terminoloških rječnika za predmetna područja, pa tako i za sport. $S$ obzirom na to da je sport društveni fenomen kojemu je jedno od ključnih obilježja njegov globalni karakter, istraživanje u ovome radu fokusira se na parametre koji opisuju skup obilježja rječnika sportskoga nazivlja. Pritom se pridjev sportski rabio u vrlo širokom značenju koje pokriva i područje pojedinih sportova i područje sportskih znanosti (anatomiju, fiziologiju, psihologiju, biomehaniku) te teoriju treninga. Cilj je rada analizirati uzorak od 103 rječnika sportskoga nazivlja s nekoliko motrišta: godinu objavljivanja, govorno područje na kojemu je rječnik objavljen, vrstu rječnika (jedno-, dvo- $i$ višejezični rječnici), jezik objavljivanja te predmetno potpodručje koje rječnik pokriva. Rezultati analize pokazuju određene trendove $u$ odnosima među analiziranim parametrima. Jedan je od ključnih, ali i očekivanih trendova taj da su rječnici objavljeni na engleskome govornom području dominantno jednojezični i najčešće su obrađivali terminologiju koja se rabi u nekoliko predmetnih potpodručja, dok su rječnici objavljeni na ne-engleskome govornom području bili dominantno više- i dvojezični te su se najčešće bavili terminologijom jednoga sporta.
\end{abstract}

Ključne riječi: predmetno potpodručje, rječnik, sport, terminologija.

\section{UVOD}

S razvojem terminologije kao znanstvene discipline, razvija se i terminografija. Prema Bergenholtzu i Kaufmannu (2017), terminografija se bavi jezikom za posebne namjene i usredotočena je na sustavnu klasifikaciju pojmovlja i nazivlja te na pripremu rječnika koji to nazivlje okupljaju. U skladu s načelima terminografije, jasno je da je uloga terminoloških rječnika prikupiti i organizirati nazivlje odabranoga predmetnog područja.

Rječnici su alat kojim bi se trebale zadovoljiti specifične potrebe korisnika (Bergenholtz i Nielsen, 2006: 283), stoga u njegovoj izradi valja na umu imati specifičnu korisničku skupinu (Araúz, Benítez i Hernández, 2008: 997). Kako bi se izradio profil specifične skupine korisnika budućega rječnika, u obzir valja uzeti brojne čimbenike, što će zajedno s tipologijom tzv. uporabne situacije (engl. use situation) odrediti pravu svrhu (engl. genuine purpose) svakoga pojedinog rječnika (Bergenholtz i Nielsen, 2006: 285). Funkcije

\footnotetext{
darija.omrcen@kif.hr
} 
su rječnika za posebne namjene brojne, a prema Tarpu (2010: 52) sve ih je moguće klasificirati na kognitivne, komunikacijske i praktične. Fata (2017: 61) govori o tri moguće ciljne skupine korisnika rječnika strukovnoga nazivlja - to su osobe koje uče jezik struke s ciljem da ga usvoje kako bi svoju kompetenciju u tome jeziku pokazale na ispitu, zatim osobe koje uče određeno predmetno područje i koji znanje o tome području istovremeno stječu i na materinskome i na stranome jeziku te budući prevoditelji i tumači koji proučavaju strategije za produkciju teksta u određenome predmetnome području i na određenome jeziku.

Vrste se rječnika određuju prema različitim kriterijima, pa tako postoje opći rječnici i rječnici za posebne namjene, zatim jednojezični, dvojezični i višejezični rječnici, tradicionalni tiskani rječnici i elektronički rječnici, online rječnici itd. Neki autori - na primjer, Laufer i Hadar (1997) - govore o jednojezičnim, dvojezičnim i odvojezičenim (engl. bilingualised) (usp. Jelaska, Cvikić i Novak, 2001: 241) rječnicima. Razni autori rabe i razne nazive za pojedine vrste rječnika, pa tako, na primjer, Aslan (2016) govori o mobilnim rječnicima (engl. mobile dictionaries) kojima se pristupa putem mobilnih uređaja (Aslan, 2016) i sl. Rječnike za posebne namjene, odnosno rječnike koji se bave terminologijom nekoga predmetnog područja, moguće je prema Tarpu (2012: 119) u zadnjih 20 godina podijeliti na tri skupine: tradicionalni tiskani rječnici, elektronički rječnici, koje objavljuju izdavačke kuće te akademske i javne institucije, te ostali mrežni rječnici. No, rječnici se mogu podijeliti i prema kriteriju broja jezika. Tako Peters i Fernández (2013) razlikuju jednojezične i dvojezične specijalizirane rječnike, Biel (2008) govori o dvojezičnim pravnim rječnicima itd.

Istraživanja rječnika strukovnoga nazivlja bavila su se raznim temama, među ostalim i pravnom terminologijom (npr. Karpinska, 2018), terminologijom računovodstva (Bergenholtz, 2012; Fuertes-Olivera, 2011; Fuertes-Olivera i Nielsen, 2011; Nielsen i Fuertes-Olivera, 2013), predstavljanjem stručnoga znanja u dvojezičnim rječnicima (Antón i Nistal, 2015), kognitivno orijentiranim strukovnim rječnicima (Fuertes-Olivera i Tarp, 2011), kolokacijama u strukovnim rječnicima (L'Homme i Leroyer, 2009), strukturom (makro- i/ili mikro-) rječnika strukovnoga jezika (Flinz, 2011; Zagórska, 2017) itd. Pojedina su se istraživanja odnosila i na nacrte za izradu pojedinih strukovnih rječnika, na primjer, rječnika računalnoga žargona (Halonja, 2008), zatim na načela i polazišta izrade enciklopedijskoga rječnika analitičke kemije (Grdinić, 2010), dok se u nekim istraživanjima sugerira izrada rječnika za pojedina predmetna područja, kao što je filozofija (Marotti, 2009). Neki se radovi bave davanjem konkretnih uputa i prijedloga za sastavljanje terminoloških rječnika (usp. Mihaljević, 2001).

$S$ razvojem društva, znanosti i tehnologije raste i broj predmetnih područja, a time i broj terminoloških rječnika za predmetna područja, 
pa tako i za sport. Prema Lipońskome (2009: 25), jezik sporta postoji od davnina, a nazivi su pojedinih drevnih sportova i rasprave o njima sačuvani $\mathrm{u}$ brojnim starim tekstovima. Isti autor navodi da je u europskim jezicima moguće pronaći gotovo 2000 sportskih naziva i izraza na grčkome jeziku. S obzirom na to da je sport društveni fenomen kojemu je jedno od ključnih obilježja njegov globalni karakter, istraživanje u ovome radu fokusira se na parametre koji ukazuju na obilježja rječnika sportskoga nazivlja.

\section{CILJ I METODOLOGIJA ISTRAŽIVANJA}

Ciljje istraživanja bio analizirati prigodni uzorak (engl. convenience sample) od 103 rječnika sportskoga nazivlja, i to s obzirom na: 1) godinu objavljivanja, 2) govorno područje na kojemu je rječnik objavljen, 3) vrstu rječnika s obzirom na broj jezika na kojima je obrađeno prikupljeno nazivlje (jedno-, dvo- i višejezični rječnici), 4) jezike (pojedinačne ili u kombinaciji) objavljivanja te 5) predmetno potpodručje koje rječnik pokriva.

Od ukupnoga broja entiteta, 96 publikacija u svome je naslovu sadržavalo naziv rječnik, dok ih je sedam sadržavalo naziv leksikon na raznim jezicima. No unatoč definicijama koje je moguće pronaći u literaturi za svaku od dvije navedene kategorije publikacija, praksa i dalje pokazuje neujednačenu uporabu njihovih naziva. S obzirom na to da u uzorku nije bilo moguće razgraničiti rječnike od leksikona prema postojećim definicijama, u ovome se radu naziv rječnik rabi kao zajednički nazivnik za obje kategorije publikacija koje okupljaju i obrađuju terminologiju sporta i pojedinih sportskih potpodručja. Neujednačenost naziva za publikacije poput rječnika i leksikona odnosi se i na nazive glosar te enciklopedijski rječnik (usp. Mihaljević, 1986, 1988: 87, 1993) u hrvatskome jeziku, a slično je i s nazivima lexicon, glossary, wordbook i thesaurus (usp. Dziemianko, 2010) te vocabularies, terminology lists (Medelyan i sur., 2013: 260) u engleskome jeziku. Što se njemačkoga jezika tiče, Schierholz (2003: 8) također napominje da je teško razlikovati nazive kao što su Wörterbuch, Lexikon, Enzyklopädie, Fachwörterbuch, Sachwörterbuch, Thesaurus i Glossar (ali i Index, Konkordanz, Allbuch ili Verzeichnis), a isto za neke od prethodno navedenih naziva kaže i Schmitz (2006: 129). Zanimljiva je i definicija hibrida koji označava kombinaciju više referentnih djela (engl. reference works), na primjer, rječnika i tezaurusa (engl. dictionary-cumthesaurus), više različitih formata (abecednoga, tematskoga) itd. (Hartmann i James, 1998: 69; Hartmann, 2005: 195). Mihaljević (1986, 1988: 87) opisane publikacije skupno naziva (terminološkim) priručnicima. Međutim, naziv priručnik se radi jednostavnijega prikaza nije rabio u ovome istraživanju kako bi se izbjegle moguće nedoumice vezane za njegovo tumačenje. Pridjev sportski se, također radi jasnijega prikaza, u ovome radu rabio u vrlo širokome značenju koje pokriva i područje pojedinih sportova i područje 
sportskih znanosti (npr. anatomiju, fiziologiju, psihologiju, biomehaniku) te teoriju treninga.

Prigodni se uzorak sastojao od: a) tiskanih rječnika dostupnih u Centru za bibliotečnu i informacijsku djelatnost - visokoškolskoj knjižnici pri Kineziološkome fakultetu Sveučilišta u Zagrebu, b) tiskanih rječnika iz privatne zbirke, c) tiskanih rječnika čiji je pregled u digitalnome obliku na mrežnim stranicama dopustio vlasnik autorskih prava (npr. izdavač), i to u opsegu koji je bio dostatan za prikupljanje podataka za ovo istraživanje, kao i d) rječnika u Portable Document Format (PDF) zapisu dostupnih na mrežnim stranicama znanstveno-istraživačkih institucija. Rječnici uključeni u uzorak objavljeni su u periodu od 1949. do 2017.

Varijabla govorno područje na kojemu je rječnik objavljen sastojala se od dvije kategorije, i to englesko govorno područje (ako je rječnik bio objavljen, na primjer, u SAD-u, Velikoj Britaniji itd.) i ne-englesko govorno područje. Pod višejezičnim rječnicima podrazumijevali su se oni u kojima je nazivlje obrađeno na tri ili više jezika.

S obzirom na velik broj prvobitnih kategorija na varijabli koja je govorila o rječničkome predmetnom području označenome pridjevom sportski, tê su kategorije, radi jasnijega prikaza rezultata, u konačnici kondenzirane na četiri, i to: terminologija sporta općenito, terminologija jednoga sporta, predmetno potpodručje - ostalo (na primjer, sportska medicina, sportska rekreacija, tjelovježba itd.) te kombinacija potpodručja. Što se naziva sportska rekreacija tiče, valja napomenuti da se u kineziološkoj literaturi vidi razlika između kineziološke i sportske rekreacije, no u ovome se radu rabi naziv sportska rekreacija koji će biti razumljiviji čitateljima koji nisu kineziolozi. Kategorizacija na toj varijabli jednim je dijelom napravljena po uzoru na podjelu strukovnih rječnika prema Bergenholtzu i Tarpu (1995: 58) - oni strukovne rječnike dijele na one koji pokrivaju nekoliko područja znanja (engl. multi-field dictionary), one koji se bave samo jednim područjem (engl. single-field dictionary) te one koji pokrivaju određeno predmetno potpodručje (engl. sub-field dictionary) unutar širega područja.

U statističkoj obradi podataka rabile su se frekvencije i postoci. Što se interakcija varijabla tiče, za ovaj je rad od njihova mogućeg ukupnog broja napravljen odabir onih za koje je procijenjeno da će svojim sadržajem u dovoljnoj mjeri ilustrirati odnose među varijablama.

\section{REZULTATI I RASPRAVA}

Što se govornoga područja tiče, u prvoj su kategoriji - englesko govorno područje-bila $42(40,8 \%$ ) entiteta, a u drugoj-ne-englesko govorno područje - njih 61 (59,2 \%). Najstariji rječnik u uzorku, a objavljen na engleskome govornom području, bio je The Dictionary of Sports Parkea Cummingsa iz 1949. i sadržavao je 12000 natuknica. Taj rječnik Lipoński (2009: 33) navodi 
kao prvi rječnik na engleskome jeziku koji je sadržavao natuknice vezane za brojne sportove najpopularnije u Sjedinjenim Američkim Državama.

Jednojezični su rječnici bili najčešća vrsta rječnika $(n=58 ; 56,3 \%)$ u analiziranome uzorku (tablica 1.), dok su se na drugome mjestu našli višejezični rječnici $(n=33 ; 32,0 \%)$. Dvojezični rječnici bili su najmanje zastupljeni u uzorku ( $\mathrm{n}=12 ; 11,7 \%)$.

Tablica 1. Distribucija učestalosti s obzirom na vrstu rječnika (jedno-, dvo- i višejezični rječnici)

\begin{tabular}{|l|c|c|}
\hline Vrsta rječnika & Frekvencija & Postotak \\
\hline Jednojezični & 58 & $56,3 \%$ \\
\hline Višejezični & 33 & $32,0 \%$ \\
\hline Dvojezični & 12 & $11,7 \%$ \\
\hline Sve skupine & 103 & $100 \%$ \\
\hline
\end{tabular}

Nogometni rječnik Fusballwörterbuch in 7 Sprachen (Kauderwelsch 203) (Yildirim, 2006) objavljen je, kako je vidljivo iz naslova, na čak sedam jezika. Prema Worldatlasu (2020a), nogomet je po broju osoba koje ga prate - a radi se o broju od oko četiri milijarde - najpopularniji sport na svijetu. Ta brojka varira od izvora do izvora, no nogomet je na svim ljestvicama na prvome mjestu, bez obzira na kriterij rangiranja. Stoga su rasprostranjenost nogometa, kao i njegova financijska strana predmet brojnih istraživanja (npr. Giulianotti i Robertson, 2004). Drugi sportovi, na primjer tenis i košarka, iako također vrlo rasprostranjeni u cijelome svijetu, značajno su manje popularni. Tako je tenis prema istome izvoru (Worldatlas, 2020a) na četvrtom mjestu s jednom milijardom osoba koje ga prate, a košarka je tek na sedmom mjestu (825 milijuna). Podaci o raširenosti pojedinih sportova u svijetu variraju ovisno o metodologiji. Tako je košarka prema izvoru Total Sportek (n. d.) sport broj dva u svijetu. Stoga je činjenica da je nogometni rječnik objavljen na čak sedam jezika argument $\mathrm{u}$ korist popularnosti toga sporta.

Što se učestalosti objavljivanja na nekome jeziku ili kombinaciji jezika tiče, tablica 2. jasno pokazuje veliki broj kategorija na toj varijabli, ali ne i veliku varijabilnost što se njihove učestalosti tiče. Nadalje, jednojezični engleski rječnici bili su najčešći u uzorku, a slijede ih višejezični (trojezični) rječnici u kojima je prikupljeno nazivlje na engleskome, francuskome i hrvatskome te peterojezični rječnici u kojima je prikupljeno nazivlje osim na engleskome i francuskome još i na ruskome, njemačkome i španjolskome jeziku. O tim će tro- i peterojezičnim rječnicima biti više riječi u daljnjoj analizi. 
OMrČEn: KvantitATIVNA ANALIZA RJEČNIKA SPORTSKOGA NAZIVlJA (STR. 89-111)

Tablica 2. Učestalost rječnika s obzirom na jezike

\begin{tabular}{|l|c|c|}
\hline JEZICI & Frekvencija & Postotak \\
\hline engleski & 45 & $43,6 \%$ \\
\hline engleski, francuski, hrvatski & 13 & $12,5 \%$ \\
\hline ruski, francuski, engleski, njemački, španjolski & 11 & $10,6 \%$ \\
\hline njemački & 3 & $2,9 \%$ \\
\hline talijanski & 2 & $1,9 \%$ \\
\hline engleski, njemački & 4 & $3,9 \%$ \\
\hline engleski, njemački, francuski & 3 & $2,9 \%$ \\
\hline engleski, španjolski & 2 & $1,9 \%$ \\
\hline slovenski & 2 & $1,9 \%$ \\
\hline španjolski & 2 & $1,9 \%$ \\
\hline engleski, talijanski & 2 & $1,9 \%$ \\
\hline češki, engleski, francuski, njemački, španjolski, ruski & 1 & $1,0 \%$ \\
\hline engleski, kineski & 1 & $1,0 \%$ \\
\hline engleski, latvijski, njemački, ruski & 1 & $1,0 \%$ \\
\hline engleski, njemački, češki & 1 & $1,0 \%$ \\
\hline engleski, njemački, francuski, talijanski, španjolski, portugalski, turski & 1 & $1,0 \%$ \\
\hline engleski, njemački, hrvatski, francuski, ruski & 1 & $1,0 \%$ \\
\hline engleski, srpski & 1 & $1,0 \%$ \\
\hline engleski, njemački, španjolski, talijanski, francuski, mađarski, ruski & 1 & $1,0 \%$ \\
\hline francuski & 1 & $1,0 \%$ \\
\hline hrvatski & 1 & $1,0 \%$ \\
\hline njemački, hrvatski & 1 & $1,0 \%$ \\
\hline ruski & 1 & $1,0 \%$ \\
\hline ruski, njemački & 1 & $1,0 \%$ \\
\hline srpski & 1 & $1,0 \%$ \\
\hline Svve skupine & 103 & $100 \%$ \\
\hline
\end{tabular}

Promatraju li se rezultati u tablici 2. s obzirom na pojedine jezike, nije iznenađujući podatak o tome da su jednojezični rječnici bili u najvećem broju slučajeva na engleskome jeziku, što je u skladu s općepoznatom činjenicom o rasprostranjenosti engleskoga jezika. Sljedeći rezultat vidljiv u tablici 2. jest taj da se francuski jezik pojavljuje u čak 32 rječnika neovisno o tome radi li se o jedno-, dvo- ili višejezičnim rječnicima. Taj je rezultat pak posljedica - možda i u najvećoj mjeri - činjenice da je francuski jedan od dva (drugi je engleski) službena jezika Međunarodnoga olimpijskoga odbora (usp. Međunarodni olimpijski odbor, 2015: 35), stoga ne čudi njegova učestalost u uzorku. Rezultat da je 29 rječnika odabralo obraditi nazivlje ili isključivo ili, među ostalim, i na njemačkome jeziku moguće je objasniti time da je taj jezik među 15 najrasprostranjenijih jezika na svijetu (prema recentnim podacima standardni njemački nalazi se na 12. mjestu - Eberhard, Simons i Fenning, 2020a) ali je, nakon ruskoga, drugi najrašireniji jezik u Europi (Worldatlas, 2020b). Potonja je činjenica važnija za analizu rezultata u ovome radu uzme 
li se u obzir prigodnost uzorka, a time i jedno od ograničenja mogućih zaključaka u ovome radu. Naime, većina je jezika na kojima je prikupljeno i sistematizirano nazivlje $\mathrm{u}$ analiziranim rječnicima pripadala indoeuropskoj skupini (osim latvijskoga, turskoga, mađarskoga i kineskoga). Što se pak učestalosti španjolskoga jezika tiče, činjenicu da je u čak 18 rječnika prikupljeno nazivlje i na tome jeziku moguće je, barem djelomično, pojasniti time da se radi o jeziku koji je na 2. mjestu po broju izvornih govornika te 4. po broju svih govornika u svijetu (Eberhard i sur., 2020b). Još jedan od rezultata koji se ističe jest taj da je 17 rječnika od ukupnoga broja u uzorku sistematiziralo nazivlje na ruskome jeziku, a to je pak moguće potkrijepiti već navedenim podatkom o rasprostranjenosti toga jezika u Europi.

Rezultati u tablici 3. pokazuju da su analizirani rječnici najčešće pokrivali terminologiju jednoga sporta $(n=42 ; 40,8 \%)$ - bilo da se radilo o pojedinačnome ili ekipnome sportu, kao i više od jednoga sportskog potpodručja ( $n=40 ; 38,8 \%)$, na primjer, terminologiju sporta i tjelovježbe, terminologiju sportskih znanosti i medicinu, sportske znanosti i teoriju treninga, tjelovježbu i prehranu itd. U kategoriji predmetno potpodručje ostalo našlo se 10 rječnika $(9,7 \%)$ koji su prikupili i obradili terminologiju potpodručja koja su se u ovome radu također svrstala pod pridjev sportski, ali se nije radilo o pojedinačnim ni ekipnim sportovima kao što su sportske igre, biciklizam, plivanje itd. Radilo se o potpodručjima poput tjelovježbe, (sportske) rekreacije, sportske medicine, teorije treninga itd., drugim riječima, o predmetnim potpodručjima sporta u najširem smislu riječi. Tako, na primjer, tjelovježba pripada skupini tzv. sportskih (engl. sporting activity) ili tjelesnih aktivnosti (engl. physical activity); sportskoj je rekreaciji cilj očuvanje i unapređenje zdravlja tjelovježbom i drugim tjelesnim aktivnostima, a sportska medicina ne bavi se samo ozljedama vrhunskih sportaša, već i osoba koje sudjeluju u drugim oblicima sportskih/tjelesnih aktivnosti.

Tablica 3. Učestalost rječnika s obzirom na predmetno potpodručje

\begin{tabular}{|l|c|c|}
\hline Predmetno potpodručje & Frekvencija & Postotak \\
\hline Terminologija sporta & 42 & $40,8 \%$ \\
\hline Kombinacija predmetnih potpodručja & 40 & $38,8 \%$ \\
\hline Terminologija sporta općenito & 11 & $10,7 \%$ \\
\hline Predmetno potpodručje - ostalo & 10 & $9,7 \%$ \\
\hline Sve skupine & 103 & $100 \%$ \\
\hline
\end{tabular}

Sportovi čiju su terminologiju rječnici obrađivali bili su, na primjer, nogomet, košarka, bejzbol, jedrenje, biciklizam, mačevanje, tenis, plivanje, vaterpolo itd. U tablici 4 . nalazi se popis više od 100 sportova čije je nazivlje prikupljeno u rječnicima u uzorku. Precizan popis nije moguće sastaviti zbog različitog označavanja sportova u rječnicima koji su sistematizirali nazivlje više od jednoga sporta, ali i zbog činjenice da u pojedinim rječnicima 
koji obrađuju terminologiju više sportova nazivlje nije (uvijek) grupirano prema sportovima, već su termini složeni abecednim redoslijedom, a oznake o pojedinom sportu za koji se neki od naziva veže nalaze se najčešće $u$ samome rječničkome članku. U prilog prvome navedenom razlogu može se pojasniti da su u nekim rječnicima pojedini sportovi ili sportske discipline tretirane pod jednim zajedničkim nazivnikom, a u drugima odvojeno - na primjer, u nekima se rabio skupni naziv borilačke vještine i pod njime su se podrazumijevale vještine poput aikida i kenda, a u drugima su te borilačke vještine promatrane odvojeno. O detaljnoj razlici između borilačkih vještina i sportova ovdje neće biti riječi - dostajat će pojašnjenje da su svi sportovi istodobno i borilačke vještine, ali sve borilačke vještine nisu istodobno i borilački sportovi. Ono što se može uočiti u tablici 4. jesu nazivi sportova za osobe s invaliditetom koji su široj publici manje poznati. Pojedini su nazivi sportova identični i kada se radi o sportovima za osobe bez invaliditeta i za osobe s invaliditetom (npr. biciklizam), dok su neki od naziva sportova za osobe bez invaliditeta modificirani kada su namijenjeni osobama s invaliditetom (npr. sjedeća odbojka, košarka u invalidskim kolicima), a ponekad se radi o sportovima kojih nema među sportovima za osobe bez invaliditeta (npr. goalball).

Tablica 4. Pregled sportova čije je nazivlje sistematizirano u rječnicima iz uzorka

\begin{tabular}{|c|c|c|c|c|c|}
\hline aikido & akrobatika & alpsko skijanje & $\begin{array}{l}\text { američki } \\
\text { nogomet }\end{array}$ & atletika & $\begin{array}{c}\text { australski } \\
\text { nogomet }\end{array}$ \\
\hline automobilizam & $\begin{array}{l}\text { bacanje } \\
\text { potkove }\end{array}$ & badminton & bendi & bejzbol & biatlon \\
\hline biciklizam & $\begin{array}{c}\text { biljar (više } \\
\text { vrsta) i snooker } \\
\text { (engl.) }\end{array}$ & $\begin{array}{c}\text { bob } \\
\text { (utrke u bobu) }\end{array}$ & boćanje & $\begin{array}{l}\text { bodybuilding } \\
\text { (engl.) }\end{array}$ & boks \\
\hline brzo klizanje & curling (engl.) & dizanje utega & džiju-džicu & džudo & $\begin{array}{l}\text { (Eton) fives } \\
\text { (engl.) }\end{array}$ \\
\hline frizbi (ultimate) & futsal & goalball (engl.) & golf & hokej na ledu & hokej na travi \\
\hline hrvanje & hurling (engl.) & irski nogomet & $\begin{array}{c}\text { jahanje na } \\
\text { valovima }\end{array}$ & jai alai (šp.) & jedrenje \\
\hline $\begin{array}{c}\text { jedrenje na } \\
\text { dasci }\end{array}$ & jedriličarstvo & kanu i kajak & karate & kendo & $\begin{array}{l}\text { kickboxing } \\
\text { (engl.) }\end{array}$ \\
\hline konjički sport & $\begin{array}{c}\begin{array}{c}\text { Korbball } \\
\text { (njem.) }\end{array} \\
\end{array}$ & košarka & $\begin{array}{c}\text { košarka u } \\
\text { kolicima }\end{array}$ & koturaljkanje & kriket \\
\hline kroket & kuglanje & kung-fu & lacrosse (fr.) & lov & mačevanje \\
\hline $\begin{array}{c}\text { mačevanje u } \\
\text { kolicima }\end{array}$ & $\begin{array}{c}\text { moderni } \\
\text { petoboj }\end{array}$ & motociklizam & netball (engl.) & nogomet & $\begin{array}{c}\text { nogomet } 5+1 \mathrm{i} \\
7+1 \text { igrača } \\
\end{array}$ \\
\hline $\begin{array}{c}\text { nordijsko } \\
\text { skijanje }\end{array}$ & odbojka & $\begin{array}{c}\text { orijentacijsko } \\
\text { trčanje }\end{array}$ & padobranstvo & $\begin{array}{c}\text { penjanje i } \\
\text { planinarenje }\end{array}$ & pétanque (fr.) \\
\hline pikado & ples & plivanje & polo & $\begin{array}{l}\text { powerlifting } \\
\text { (engl.) }\end{array}$ & ragbi \\
\hline
\end{tabular}




\begin{tabular}{|c|c|c|c|c|c|}
\hline $\begin{array}{c}\text { ragbi u } \\
\text { invalidskim } \\
\text { kolicima }\end{array}$ & $\begin{array}{c}\text { racketball / } \\
\text { racquetball } \\
\text { (engl.) }\end{array}$ & ribolov & $\begin{array}{c}\text { ritmička } \\
\text { gimnastika }\end{array}$ & rodeo & ronjenje \\
\hline rounders (engl.) & rukomet & sanjkanje & $\begin{array}{c}\text { sepak takraw } \\
\text { (malaj./tajl.) }\end{array}$ & $\begin{array}{c}\text { sinkronizirano } \\
\text { plivanje }\end{array}$ & $\begin{array}{c}\text { sjedeća } \\
\text { odbojka }\end{array}$ \\
\hline $\begin{array}{c}\text { skateboarding } \\
\text { (engl.) }\end{array}$ & $\begin{array}{c}\text { skeleton } \\
\text { (engl. < grč.) }\end{array}$ & $\begin{array}{c}\text { skijanje na } \\
\text { vodi }\end{array}$ & $\begin{array}{c}\text { skijanje } \\
\text { slobodnim } \\
\text { načinom }\end{array}$ & $\begin{array}{c}\text { skokovi u } \\
\text { vodu }\end{array}$ & $\begin{array}{c}\text { snowboarding } \\
\text { (engl.) }\end{array}$ \\
\hline softball (engl.) & $\begin{array}{c}\text { sportska } \\
\text { gimnastika }\end{array}$ & squash (engl.) & $\begin{array}{c}\text { taekwondo } \\
\text { (kor.) }\end{array}$ & tenis & $\begin{array}{c}\text { tenis u } \\
\text { kolicima }\end{array}$ \\
\hline $\begin{array}{c}\text { stolni tenis } \\
\text { streličarstvo }\end{array}$ & streljaštvo & trampolin & triatlon & $\begin{array}{c}\text { umjetničko } \\
\text { klizanje }\end{array}$ \\
\hline $\begin{array}{c}\text { utrke motornih } \\
\text { čamaca }\end{array}$ & utrke pasa & $\begin{array}{c}\text { utrke psećih } \\
\text { zaprega }\end{array}$ & vaterpolo & veslanje & zmajarenje \\
\hline
\end{tabular}

$\mathrm{U}$ analiziranim rječnicima nalaze se i aktivnosti manje poznate široj publici za koje bi se moglo reći da je pomalo iznenađujuće da su uvrštene $\mathrm{u}$ rječnike sa zajedničkim nazivnikom sportski. No ne propitujući razloge za njihovo uključivanje u rječnike, moguće je istaknuti nekoliko primjera. Tako Cummings u svoj rječnik (1949: 214), među ostalim, uključuje i nazivlje vezano za bacanje potkove (engl. horseshoe pitching) tumačeći tu aktivnost kao sport, dok rodeo u svoj rječnik uključuje, na primjer, Room (2010) koji ga - kao što to čini Cummings za bacanje potkove - također opisuje kao sport (usp. Room, 2010: 125). Room (2010) obrađuje i nazivlje vezano za pétanque (fr.) (usp. Room, 2010: 110) - igru sličnu boćanju (u Hrvatskoj su prema dostupnim podacima četiri pétanque kluba - Novilist.hr, 2019). Ono što je moguće dodati $u$ analizu tablice 4 . jest to da je u rječnicima bilo prikupljeno nazivlje sportova poznatih širokoj publici (poput nogometa, košarke, tenisa itd.), ali i sportova koji su manje poznati u zemljama koje nisu članice svjetskih krovnih udruga pojedinih sportova. Tako, na primjer, Hrvatska nije članica Međunarodnoga bendijskog saveza, no radi se o sportu koji se igra u zemljama sa svih strana svijeta i trenutačno je 27 članica toga Saveza (Federation of International Bandy, n. d.). Stoga će vjerojatno relativno mali broj ljudi u Hrvatskoj znati da se radi o igri sličnoj hokeju na ledu koja je i preteča toga sporta. Lacrosse - također u Hrvatskoj relativno nepoznat širokoj publici (Hrvatski lacrosse savez osnovan je 2018. - Croatia lacrosse, 2020), sport je koji se smatra jednim od najstarijih organiziranih sportova $u$ Sjevernoj Americi, a broj članica svjetske krovne udruge toga sporta - World Lacrosse, veći je od 60. Kao treći primjer može poslužiti igra pod nazivom rounders (engl.), koja je unatoč činjenici da je vjerojatno preteča bejzbola (Encyclopaedia Britannica, 2020) - jednoga od danas vrlo raširenih sportova - danas geografski relativno malo raširena i igra se pretežno na području Velike Britanije. 
Detaljniji pogled $\mathrm{u}$ navedene rječnike pokazuje da je $\mathrm{u}$ toj kategoriji najveći broj rječnika obrađivao nogometnu terminologiju, a uzmu li se $u$ obzir prethodni podaci o rasprostranjenosti nogometa, takav se rezultat čini logičnim - čak osam od ukupno 42 rječnika koji obrađuju terminologiju nekoga sporta bilo je posvećeno nazivlju toga sporta. Doda li se ukupnome broju od 42 rječnika posvećenih terminologiji pojedinih sportova podatak da je 11 rječnika obrađivalo terminologiju sporta općenito, dakle, bavili su se terminologijom više od jednoga sporta, jasno je da su čak 53 rječnika, odnosno 51,5 \% od ukupnoga broja u uzorku, za svoju domenu odabrala potpodručja u smislu pojedinačnih i ekipnih sportova kao sportskih aktivnosti. Terminologija se $u$ njima odnosila na pojedine elemente igre (ako se radilo o sportskim igrama, na primjer, o nogometu, košarci, tenisu itd.), elemente tehnike, pravila i sl.

\subsection{Interakcije varijabla}

3.1.1. Interakcija varijabla govorno područje na kojemu je rječnik objavljen i godina objavljivanja

Promatraju li se pojedine godine, najviše je rječnika iz uzorka objavljeno 1987. $(n=15)$ i 1979. $(n=14)$. U ostalim godinama obuhvaćenima u ovome istraživanju broj objavljenih rječnika bio je značajno manji i kretao se, promatraju li se oba govorna područja zajedno, u rasponu od jedan do sedam. Od ukupno 15 rječnika objavljenih 1987., 13 ih dolazi s ne-engleskoga, a tek dva s engleskoga govornog područja, dok svih 14 rječnika iz 1979. dolazi s ne-engleskoga govornog područja (slika 1.).

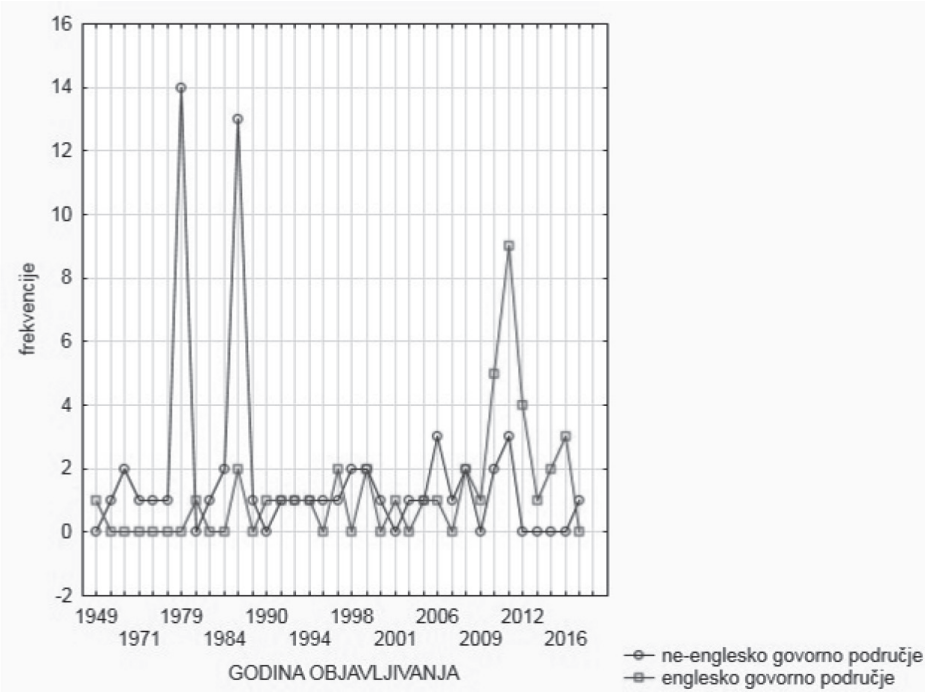

Slika 1. Interkacija varijabla govorno područje na kojemu je rječnik objavljen i godina objavljivanja 
Podaci navedeni za 1979. i 1987. u skladu su s pojavom koju opisuje Lipoński (2009: 33), a ta je da, na primjer, u Poljskoj objavljivanje dvojezičnih sportskih rječnika često prati održavanje međunarodnih sportskih natjecanja. Iako ni jedan od rječnika uključenih u uzorak u ovome radu nije bio iz Poljske, pojava koju Lipoński (ibid.) opisuje ilustrativna je za rječnike objavljene povodom Univerzijade održane u Zagrebu 1987. (njih 12 od ukupno 15 rječnika u 1987.), kao i za 12 (od ukupno 14) rječnika objavljenih 1979. u Moskvi, tj. u godini koja je prethodila Olimpijskim igrama u tome gradu 1980. Što se pak 2011. i 12 rječnika objavljenih te godine tiče, iako se radi o godini koja prethodi Olimpijskim igrama u Londonu 2012., taj veliki sportski događaj nije bio povod za veću učestalost objavljivanja rječnika (tri s neengleskoga i devet s engleskoga govornog područja). Razlog veće učestalosti je objavljivanje serijala rječnika koje kao zajednički nazivnik povezuju dvije riječi iz njihovih naziva - historical dictionary (hrv. povijesni rječnik). Tako su u sklopu navedena serijala objavljeni, na primjer, rječnici skijanja, biciklizma, nogometa, tenisa, umjetničkoga klizanja i golfa - njih ukupno šest. K tomu je iste godine, također sa zajedničkim nazivnikom historical dictionary u nazivu publikacije, objavljen i rječnik olimpijskoga pokreta (v. Mallon i Heijmans, 2011).

\subsubsection{Interakcija varijabla govorno područje na kojemu je rječnik objavljen i vrsta rječnika}

Najveći je broj višejezičnih rječnika u analiziranome uzorku bio objavljen na ne-engleskome govornom području (tablica 5.). Tome je broju među ostalim značajno doprinio broj višejezičnih, i to trojezičnih, rječnika objavljenih u Hrvatskoj. Tajje rezultat u skladu s činjenicom da se radi o prigodnome uzroku $\mathrm{s}$ jedne strane, ali i da, s druge, on postaje jasniji kada se navede činjenica da se radi o čak 12 rječnika objavljenih povodom održavanja Univerzijade u Zagrebu 1987. Rječnici objavljeni u vrijeme toga sportskog događaja na svjetskoj razini, a koji su bili dio uzorka u ovome istraživanju, obrađivali su terminologiju raznih sportova, na primjer, nogometa, košarke, plivanja itd., i to na hrvatskome, engleskome i francuskome jeziku. Uz hrvatski, koji je bio logičan odabir s obzirom na mjesto održavanja Univerzijade i jezik njezina domaćina, druga dva jezika - engleski i francuski - odabrani su kao službeni jezici Međunarodnoga olimpijskoga odbora (usp. Međunarodni olimpijski odbor, 2015: 35). Jedan od rječnika novijega datuma objavljenih u Hrvatskoj jest i trojezični Rječnik olimpijskih i paraolimpijskih športova / englesko-francuskohrvatski (Ujlaki Subić, 2010), koji slijedi načelo rječnika objavljenih u vrijeme Univerzijade održane u Zagrebu i obrađuje nazivlje na hrvatskome jeziku te na dva službena jezika Međunarodnoga olimpijskog odbora. 
Tablica 5. Interakcija varijabla govorno područje na kojemu je rječnik objavljen i vrsta rječnika

\begin{tabular}{|c|c|c|c|c|c|}
\hline & \multirow[b]{2}{*}{$\begin{array}{l}\text { Govorno } \\
\text { područje }\end{array}$} & \multicolumn{4}{|c|}{ Vrsta rječnika } \\
\hline & & \begin{tabular}{|c|} 
Jednojezični \\
rječnici
\end{tabular} & $\begin{array}{l}\text { Dvojezični } \\
\text { rječnici }\end{array}$ & $\begin{array}{l}\text { Višejezični } \\
\text { rječnici }\end{array}$ & $\begin{array}{c}\text { Ukupno po } \\
\text { retku }\end{array}$ \\
\hline Frekvencija & \multirow{3}{*}{$\begin{array}{l}\text { Ne-englesko } \\
\text { govorno } \\
\text { područje }\end{array}$} & 17 & 11 & 33 & 61 \\
\hline Postotak po stupcu & & $29,3 \%$ & $91,7 \%$ & $100,0 \%$ & \\
\hline Postotak po retku & & $27,9 \%$ & $18,0 \%$ & $54,1 \%$ & \\
\hline Frekvencija & \multirow{3}{*}{$\begin{array}{l}\text { Englesko } \\
\text { govorno } \\
\text { područje }\end{array}$} & 41 & 1 & 0 & 42 \\
\hline Postotak po stupcu & & $70,7 \%$ & $8,3 \%$ & $0,0 \%$ & \\
\hline Postotak po retku & & $97,6 \%$ & $2,4 \%$ & $0,0 \%$ & \\
\hline Frekvencija & Sve skupine & 58 & 12 & 33 & 103 \\
\hline
\end{tabular}

Najveći broj jednojezičnih rječnika objavljen je na engleskome govornom području $(n=41)$. S jedne je strane takav rezultat bio i očekivan. No iznenađuje činjenica da broj dvojezičnih rječnika objavljenih na engleskome govornom području ipak nije bio veći unatoč mogućoj komercijalnoj opravdanosti objavljivanja i na drugim jezicima uzme li se u obzir veličina potencijalnoga tržišta u vidu brojnosti govornika drugih jezika u svijetu - na primjer, španjolskoga (534 milijuna izvornih govornika - Eberhard i sur., 2020a) te 234 milijuna izvornih govornika portugalskoga (Eberhard i sur., 2020a). Na engleskome govornom području izostaje i objavljivanje višejezičnih rječnika povodom svjetskih sportskih nadmetanja iako su se na njemu održale, na primjer, ljetne Olimpijske igre u Londonu 2012., Salt Lake Cityju 2002., Sydneyju 2000, Atlanti 1996., Los Angelesu 1984. itd., kao i zimske Olimpijske igre u Salt Lake Cityju 2002., Lake Placidu 1980. itd.

Drugim riječima, od ukupno 12 dvojezičnih rječnika u uzorku većina (njih 11) bili su objavljeni na ne-engleskome govornom području. Jedini dvojezični rječnik $\mathrm{u}$ analiziranome uzorku, a koji je objavljen na engleskome govornom području bio je Bilingual Baseball Dictionary - English-Spanish, Spanish-English (O'Neill, 2009). Drugi je značajan podatak da na engleskome govornom području nije bio objavljen nijedan višejezični rječnik - svi su objavljeni na ne-engleskome govornom području. Pritom valja uzeti u obzir činjenicu da je uzorak u istraživanju u ovome radu bio prigodan, tj. obrađeni su rječnici za koje su se mogli prikupiti podaci potrebni za analizu. No rezultat je unatoč tomu iznenađujući. On znači da su se izdavači koji rade na engleskome govornom području odlučili dominantno za jednojezične rječnike na engleskome jeziku, dokjednojezični rječnici nisubili prviizborizdavačas drugih govornih područja. O razlozima izdavača s engleskoga govornog područja za odabir jednojezičnih rječnika kao preferirane vrste rječnika može se samo nagađati. No ono što je sigurno jest to da je izrada dvo- i višejezičnih rječnika za neko strukovno područje vrlo složen posao koji zahtijeva i poznavanje predmetnoga područja i višejezičnu kompetenciju. Moguće je da je baš višejezična kompetencija ta koja je u ovome slučaju bila presudan čimbenik. Naime, stručnjaci - predmetni 
eksperti i/ili jezikoslovci - s ne-engleskih govornih područja nastoje strukovno nazivlje na drugim jezicima uskladiti ili usporediti s nazivljem na engleskome jeziku, što rezultira publikacijama koje nazivlje pojedine struke obrađuje na više od jednoga jezika.

Tipičan je korisnik, na primjer, dvojezičnoga rječnika prema Pietrowskome (1994: 23): a) dvojezična osoba (Pietrowski rabi riječ bilingual) koja ima nedovoljno znanje u nekim aspektima bilo kojega od dva jezika, a kojoj je to znanje potrebno kako bi prenijela određene poruke (bilo u L1 ili u L2), b) osoba koja želi postati dvojezična i komunicirati s govornicima na stranome jeziku ili c) osoba koja ne želi postati dvojezična, ali želi komunicirati na razini razumijevanja (npr. znanstvenici, turisti itd.). Iako, preferencije su koje se odnose na uporabu jednojezičnih i dvojezičnih rječnika u osoba koje uče neki strani jezik različite. Prema Guu (2003), različiti autori o tome iznose različite stavove. Tako, na primjer, Lew (2004: 178) smatra da osobe koje uče neki strani jezik - a pretpostavlja se da se najčešće radi o osobama s ne-engleskih govornih područja - preferiraju dvojezične rječnike u odnosu na jednojezične. Kunzmann-Müller (2001: 161) smatra da su dvoi višejezični rječnici alat svih onih koji strani jezik ili primjenjuju u praksi ili se njime bave u nastavi stranih jezika. Stoga je objavljivanje dvojezičnih rječnika logičan izbor autora i izdavača. Iako su se navedena istraživanja odnosila na opći jezik, situacija je slična i kada se radi o strukovnim jezicima. No ovdje valja istaknuti da su višejezični rječnici bili čak češći od dvojezičnih na ne-engleskome govornom području.

Pritom valja naglasiti činjenicu da su jednojezični rječnici, iako su u svome nazivu imali riječ dictionary (hrv. rječnik), u suštini bili pojmovnici koji su osim naziva navodili i opise pojmova koje ti nazivi označavaju. Iako se takve publikacije ne bave toliko jezikom koliko su same po sebi kompendiji (naziv koji rabi Lew) znanja u pojedinim predmetnim područjima (Lew, 2015: 1), vrijednost je takvih rječnika za terminologiju i terminografiju ogromna i neosporna te predstavlja temelj za standardizaciju nazivlja bilo koje struke. Stoga je njihova učestalost na ne-engleskome govornom području $(n=17)$ značajna i važna za rad na terminologiji sporta.

\subsubsection{Interakcija varijabla govorno područje na kojemu je rječnik objavljen $i$ predmetno potpodručje}

Interakcija varijabla govorno područje na kojemu je rječnik objavljen i predmetno potpodručje pokazala je (tablica 6.) da su rječnici objavljeni na engleskome govornom području najčešće obrađivali terminologiju koja se rabi u nekoliko predmetnih potpodručja, tj. u kombinaciji nekoliko potpodručja vezanih za sport. Druga najčešća kategorija rječnika objavljenih na tome govornom području bili su oni u kojima je prikupljena terminologija pojedinih sportova, a treća su kategorija po učestalosti bili rječnici koji su obrađivali terminologiju 
jednoga potpodručja, i to onoga koje nije obrađivalo pojedinačne i ekipne sportove, odnosno elemente njihove tehnike, taktike ili njihova pravila, već su se bavili terminologijom, na primjer, sportske medicine i teorije treninga.

Tablica 6. Interakcija varijabla govorno područje na kojemu je rječnik objavljen i predmetno potpodručje

\begin{tabular}{|c|c|c|c|c|c|c|}
\hline & \multirow[b]{2}{*}{$\begin{array}{l}\text { Govorno } \\
\text { područje }\end{array}$} & \multicolumn{5}{|c|}{ Predmetno potpodručje } \\
\hline & & $\begin{array}{c}\text { Terminologija } \\
\text { sporta } \\
\text { općenito } \\
\end{array}$ & $\begin{array}{c}\text { Terminologija } \\
\text { sporta }\end{array}$ & \begin{tabular}{|c|} 
Kombinacija \\
predmetnih \\
potpodručja
\end{tabular} & \begin{tabular}{|c|} 
Predmetno \\
potpodručje \\
- ostalo \\
\end{tabular} & $\begin{array}{l}\text { Ukupno } \\
\text { po retku }\end{array}$ \\
\hline Frekvencija & \multirow{3}{*}{$\begin{array}{l}\text { Ne-englesko } \\
\text { govorno } \\
\text { područje }\end{array}$} & 9 & 29 & 20 & 3 & 61 \\
\hline $\begin{array}{l}\text { Postotak po } \\
\text { stupcu }\end{array}$ & & $81,8 \%$ & $69,1 \%$ & $50,0 \%$ & $30,0 \%$ & \\
\hline $\begin{array}{l}\text { Postotak po } \\
\text { retku }\end{array}$ & & $14,8 \%$ & $47,5 \%$ & $32,8 \%$ & $4,9 \%$ & \\
\hline Frekvencija & \multirow{3}{*}{$\begin{array}{l}\text { Englesko } \\
\text { govorno } \\
\text { područje }\end{array}$} & 2 & 13 & 20 & 7 & 42 \\
\hline $\begin{array}{l}\text { Postotak po } \\
\text { stupcu }\end{array}$ & & $18,2 \%$ & $30,9 \%$ & $50,0 \%$ & $70,0 \%$ & \\
\hline $\begin{array}{l}\text { Postotak po } \\
\text { retku }\end{array}$ & & $4,8 \%$ & $30,9 \%$ & $47,6 \%$ & $16,7 \%$ & \\
\hline Frekvencija & Sve skupine & 11 & 42 & 40 & 10 & 103 \\
\hline
\end{tabular}

Zanimljivoje također da su se rječnici objavljeni na engleskome govornom području najrjeđe bavili kolektivno terminologijom više sportova. Za razliku od njih rječnici objavljeni na ne-engleskome govornom području najčešće su se bavili terminologijom pojedinoga sporta, a zatim kombinacijom potpodručja, poput englesko-talijanskoga rječnika Dizionario dello sport e di medicina sportiva inglese-italiano, italiano-inglese (Bonanno, 1988), dok je na neengleskome govornom području učestalost rječnika koji su se bavili jednim predmetnim potpodručjem koje se nije izravno odnosilo na terminologiju pojedinih sportova i terminologijom sportova bila najniža.

Izrada i dvojezičnih i višejezičnih rječnika često nailazi na brojne probleme od kojih je jedan nepostojanje naziva s istom komunikacijskom vrijednošću u drugim jezicima. Drugi su problemi sinonimija, koja nije poželjna u strukovnome jeziku, ali ju nije moguće ni izbjeći, te polisemija (usp. Pisanelli i sur., 2004) koja zahtijeva vrlo visoku razinu poznavanja terminologije u specifičnim potpodručjima.

\subsubsection{Interakcija varijabla jezik i godina objavljivanja}

Na slici 2. prikazana je interakcija varijable jezik i varijable godina objavljivanja. U prvoj od te dvije varijable rječnici su kategorizirani prema jeziku, tj. jezicima objavljivanja. Na slici se snažnije od ostalih ističu tri rezultata. Prvi je taj da broj jednojezičnih engleskih rječnika od polovice osamdesetih godina prošloga stoljeća počinje rasti i doseže vrhunac 2011. No taj je rezultat 
u velikoj mjeri posljedica izdavačke politike nakladnika Rowman i Littlefield koji - kako je prethodno opisano - 2010. počinje s objavljivanjem serijala rječnika sa zajedničkim nazivnikom povijesni rječnik nekolicine sportova. Te su godine objavljena dva takva rječnika, 2011. njih sedam te 2012. tri. Kako je vidljivo iz slike 2., rezultat je toga trenda bio značajno veći broj ukupno objavljenih jednojezičnih engleskih rječnika u tim trima godinama.

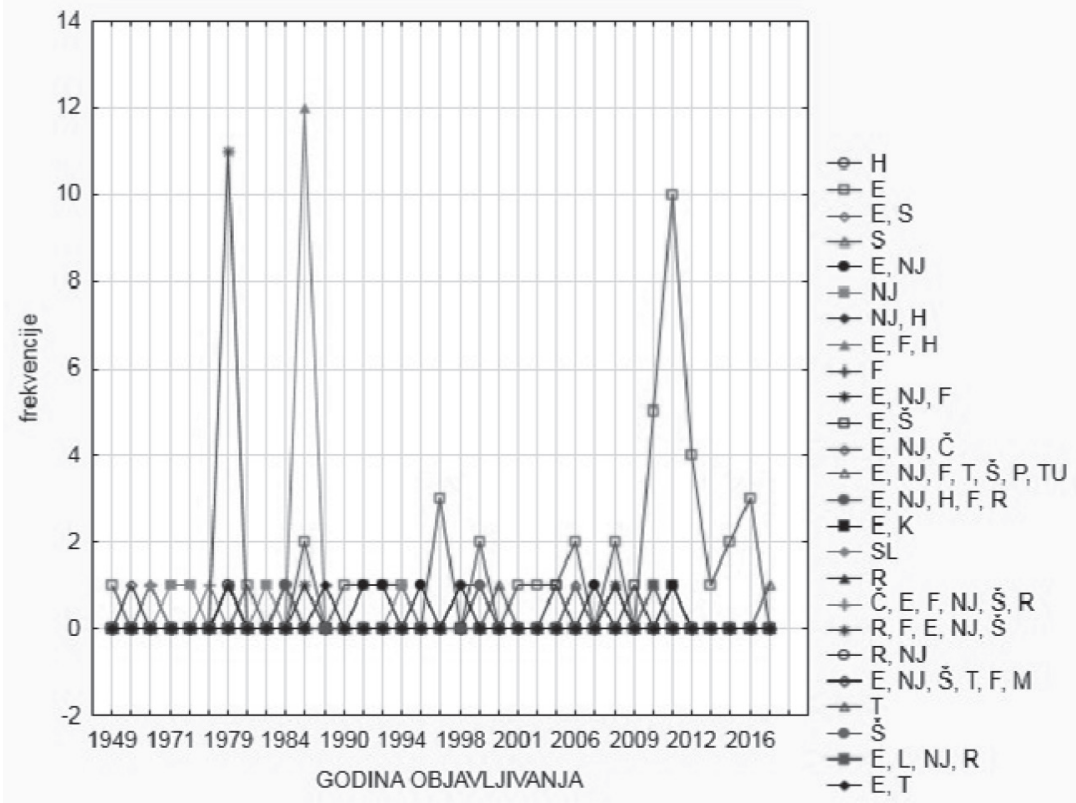

Legenda: $\check{C}$ - češki, E-engleski, F-francuski, $H$ - hrvatski, K- kineski, L-latvijski,

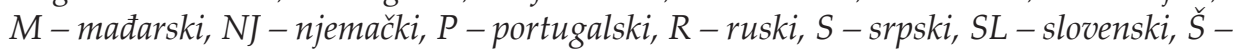
španjolski, T-talijanski, TU-turski

Slika 2. Interakcija varijabla jezik i godina objavljivanja

Druga dva rezultata koji se ističu odnose se na dvije godine, i to 1979. i 1987. Kako je već prethodno pojašnjeno, radi se o godinama koje su vezane za održavanje dva velika sportska natjecanja - 1979. prethodi godini u kojoj su se održale Olimpijske igre u Moskvi, a 1987. je održana Univerzijada u Zagrebu. Slika 2. pokazuje da se u oba slučaja radi o višejezičnim rječnicima - 1987. povodom Univerzijade u Zagrebu objavljeni su rječnici u kojima je bilo prikupljeno nazivlje na tri jezika, i to na engleskome, francuskome i hrvatskome, dok je u rječnicima objavljenima 1979. - povodom Olimpijskih igara u Moskvi 1980., bilo prikupljeno nazivlje na ruskome, francuskome, engleskome, njemačkome i španjolskome jeziku. 


\subsubsection{Interakcija varijabla jezik i vrsta rječnika}

Promotri li se interakcija varijabla jezik i vrsta rječnika (slika 3.), očigledno je da su jednojezični rječnici dominantno prikupljali nazivlje na engleskome jeziku, dok je učestalost rječnika u kojima je prikupljeno nazivlje na više od jednoga jezika s obzirom na vrstu rječnika bila manja od pet, osim u dva slučaja koja su se odnosila na višejezične rječnike. Taj se rezultat već implicitno pojavljivao u prethodnim rezultatima. Naime, radi se o učestalosti koja se ističe uslijed već u nekoliko navrata spomenutih višejezičnih rječnika objavljenih povodom Olimpijskih igara u Moskvi i povodom Univerzijade u Zagrebu. Uz njih učestalost višejezičnih rječnika povećali su i neki drugi, na primjer, trojezični Wörterbuch der Sportwissenschaft: Deutsch - Englisch - Französisch / Dictionary of Sport Science: German - English - French / Dictionnaire des sciences du sport: Allemand - Anglais - Français urednika Ericha Beyera (1987), šesterojezični rječnik urednika Ferenca Heppa iz 1960. u kojemu je prikupljeno nazivlje specifično za plivanje, vaterpolo, skokove u vodu i sinkronizirano plivanje za koje se $\mathrm{u}$ to vrijeme $\mathrm{u}$ engleskome jeziku rabio naziv koji rabi i Hepp - fancy swimming (uengleskome suga takođernazivaliiornamental swimming), a nazivlje je prikupljeno na engleskome, njemačkome, španjolskome, francuskome, mađarskome i ruskome jeziku, te sedmerojezični rječnik K. Yildirima iz 2006. u kojemu je prikupljeno nogometno nazivlje, i to na engleskome, njemačkome, francuskome, talijanskome, španjolskome, portugalskome i turskome jeziku.

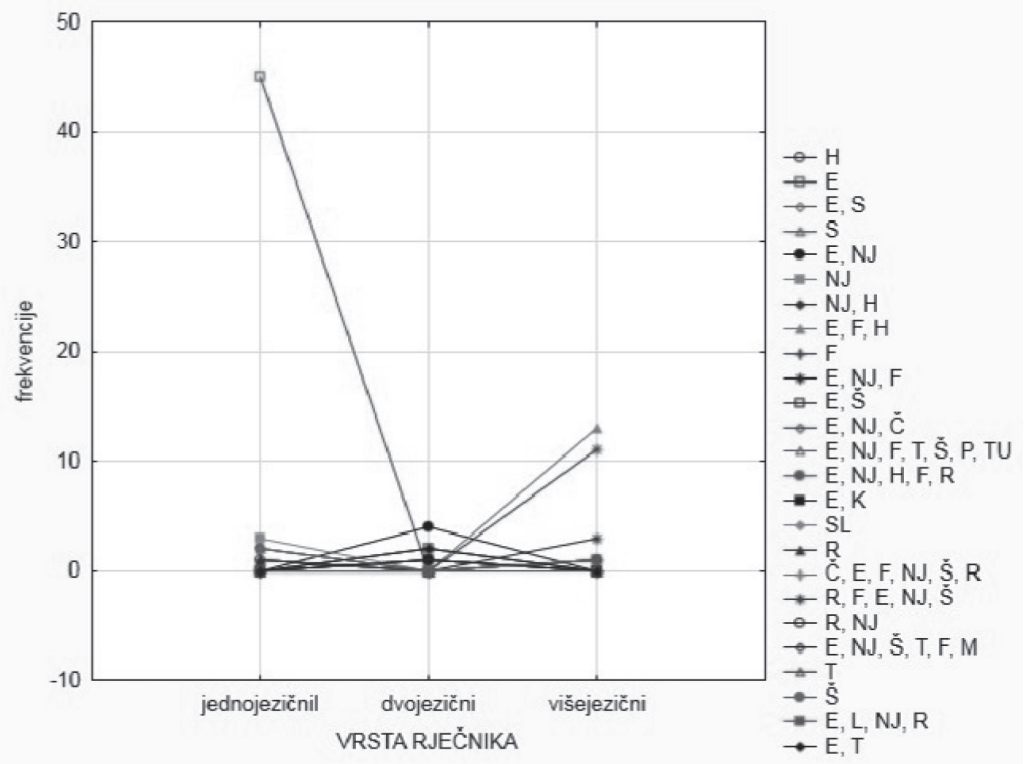

Legenda: $\check{C}$ - čěski, E-engleski, F-francuski, H-hrvatski, K-kineski, L-latvijski, M-mađarski, NJ-

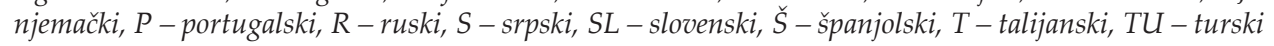

Slika 3. Interakcija varijabla jezik i vrsta rječnika 


\subsubsection{Interakcija varijabla jezik i govorno područje}

Ključan rezultat koji se vidi na slici 4 . govori o tri činjenice. Prva je, što je bilo očekivano, da su na engleskome govornom području objavljeni dominantno rječnici koji su prikupili i obradili nazivlje na engleskome jeziku. Druga je, također očekivana, činjenica vezana za podatak da su na ne-engleskome govornom području dominantno objavljeni rječnici u kojima je prikupljeno nazivlje i na drugim jezicima (pojedinačnim ili njihovim kombinacijama). Stoga spomenuta dva rezultata ne začuđuju. No zanimljivo je vidjeti koji su to rječnici objavljeni na engleskome govornom području koji su prikupili i sistematizirali nazivlje i na nekom drugom jeziku osim engleskoga. Od ukupnoga uzorka rječnika u ovome istraživanju takav je bio samo jedan - radi se o dvojezičnome O'Neillovu (2009) rječniku u kojemu je sistematizirano nazivlje specifično za bejzbol, i to na engleskome i španjolskome.

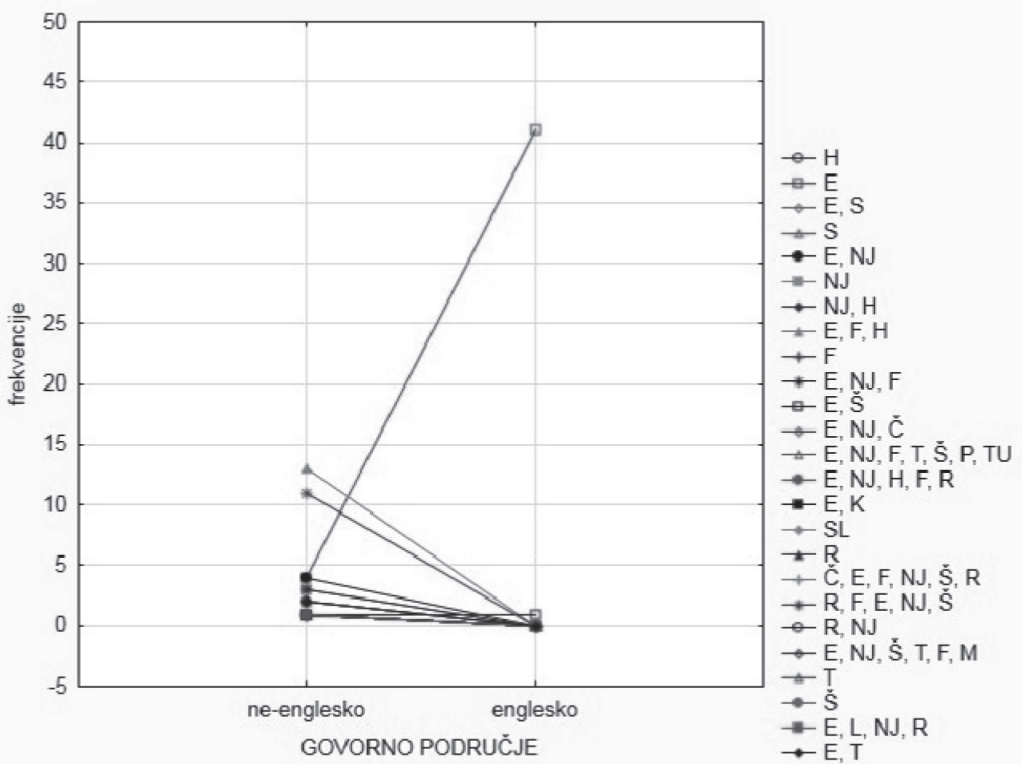

Legenda: $\check{C}$ - češki, E-engleski, F-francuski, H-hrvatski, K-kineski, L-latvijski, $M$ - mađarski, NJ-

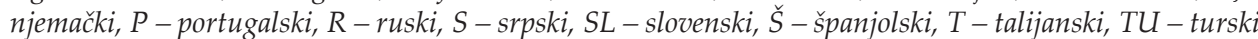

Slika 4. Interakcija varijabla jezik i govorno područje

Taj rezultat govori pak o nečemu o čemu je već prethodno bilo riječi. Radi se o dva aspekta. Prvi se odnosi na odabir engleskoga kao dominantnog jezika publikacija nakladnika s engleskoga govornog područja, a temelji se na općepoznatoj činjenici o engleskome kao najraširenijem jeziku na svijetu - prema broju izvornih govornika taj se jezik nalazi iza mandarinskoga kineskog i španjolskoga, no po broju govornika je na prvome mjestu (Eberhard i sur., 2020b). Drugi se aspekt odnosi na raširenost španjolskoga 
jezika koji je, kako je prethodno rečeno, drugi po broju izvornih govornika u svijetu, a četvrti - nakon Hindija - po broju svih govornika (Eberhard i sur., 2020b). Pritom je nezaobilazan i podatak da je bejzbol vrlo raširen $u$ Središnjoj i Južnoj Americi, odnosno preciznije, na sjeveru Južne Amerike, tj. na geografskome području na kojemu je najrašireniji jezik španjolski. Važnu ulogu u širenju bejzbola na tome području imala je Kuba, i to počevši od osnivanja Kubanske lige 1878. (usp. Echevarría, 1999; Figueredo, 2003) koju se smatra najstarijom i najdugovječnijom (prestala je postojati 1961.) profesionalnom bejzbolskom ligom izvan Sjedinjenih Američkih Država.

\subsubsection{Interakcija varijabla vrsta rječnika i predmetno potpodručje}

Tablica 7. pokazuje da su rječnici koji su obrađivali terminologiju više od jednoga predmetnog potpodručja najčešće bili jednojezični, značajno rjeđe dvojezični, a najrjeđe višejezični. Taj je rezultat moguće objasniti činjenicom da je obrađivanje terminologije više od jednoga predmetnog potpodručja bilo vrlo zahtjevno te je jednojezičnost rječnika bila najčešći odabir.

\begin{tabular}{|c|c|c|c|c|c|c|}
\hline & \multirow[b]{2}{*}{$\begin{array}{c}\text { Vrsta } \\
\text { rječnika }\end{array}$} & \multicolumn{5}{|c|}{ Predmetno potpodručje } \\
\hline & & $\begin{array}{c}\text { Terminologija } \\
\text { sporta općenito }\end{array}$ & $\begin{array}{c}\text { Terminologija } \\
\text { sporta }\end{array}$ & $\begin{array}{l}\text { Kombinacija } \\
\text { predmetnih } \\
\text { potpodručja }\end{array}$ & \begin{tabular}{|c|} 
Predmetno \\
potpodručje \\
- ostalo
\end{tabular} & $\begin{array}{l}\text { Ukupno } \\
\text { po retku }\end{array}$ \\
\hline Frekvencija & \multirow{3}{*}{$\begin{array}{l}\text { Jednojezični } \\
\text { rječnici }\end{array}$} & 5 & 15 & 29 & 9 & 58 \\
\hline $\begin{array}{l}\text { Postotak po } \\
\text { stupcu }\end{array}$ & & $45,4 \%$ & $35,7 \%$ & $72,5 \%$ & $90,0 \%$ & \\
\hline $\begin{array}{l}\text { Postotak po } \\
\text { retku }\end{array}$ & & $8,6 \%$ & $25,9 \%$ & $50,0 \%$ & $15,5 \%$ & \\
\hline Frekvencija & \multirow{3}{*}{$\begin{array}{l}\text { Dvojezični } \\
\text { rječnici }\end{array}$} & 2 & 2 & 8 & 0 & 12 \\
\hline $\begin{array}{l}\text { Postotak po } \\
\text { stupcu }\end{array}$ & & $18,2 \%$ & $4,8 \%$ & $20,0 \%$ & $0,0 \%$ & \\
\hline $\begin{array}{l}\text { Postotak po } \\
\text { retku }\end{array}$ & & $16,7 \%$ & $16,7 \%$ & $66,7 \%$ & $0,0 \%$ & \\
\hline Frekvencija & \multirow{3}{*}{$\begin{array}{l}\text { Višejezični } \\
\text { rječnici }\end{array}$} & 4 & 25 & 3 & 1 & 33 \\
\hline $\begin{array}{l}\text { Postotak po } \\
\text { stupcu }\end{array}$ & & $36,4 \%$ & $59,5 \%$ & $7,5 \%$ & $10,0 \%$ & \\
\hline $\begin{array}{l}\text { Postotak po } \\
\text { retku }\end{array}$ & & $12,1 \%$ & $75,8 \%$ & $9,1 \%$ & $3,0 \%$ & \\
\hline Frekvencija & Sve skupine & 11 & 42 & 40 & 10 & 103 \\
\hline
\end{tabular}

S druge pak strane, višejezični su rječnici bili najčešća opcija kada su se rječnici bavili terminologijom samo jednoga sporta. Navedenome rezultatu pridonose rječnici objavljeni u Hrvatskoj, ali i u nekim drugim zemljama, na primjer, u Rusiji. Potonji su objavljeni povodom Olimpijskih igara u Moskvi 1980.- od ukupno 12 takvih rječnika uključenih u uzorak u ovome radu, njih 11 
bavilo se terminologijom isključivo jednoga sporta. No za razliku od rječnika objavljenih povodom Univerzijade 1987. u Zagrebu, a koji su bili trojezični (hrvatski, engleski, francuski), tih je 11 rječnika obrađivalo terminologiju na pet jezika-ruskome, francuskome, engleskome, njemačkome i španjolskome. No ističe se i rezultat koji govori o tome da su se po učestalosti terminologijom pojedinih sportova odmah nakon višejezičnih bavili jednojezični rječnici, a radi se o rječnicima koji su najčešće bili na engleskome jeziku i koji su bili objavljeni na engleskome govornom području.

\section{ZAKLJUČAK}

Iako je uzorak u ovome istraživanju bio prigodan, analiza je pokazala nekoliko ključnih obilježja sportskih rječnika i trendova njihova objavljivanja. Kao prvo, analiza je pokazala da je u rječnicima najčešće prikupljeno i sistematizirano nazivlje na engleskome jeziku, zatim na francuskome, njemačkome i španjolskome, a razlozi su tome njihova rasprostranjenost, kao i dodatna činjenica da su engleski i francuski službeni jezici Međunarodnoga olimpijskog odbora. Kao drugo, broj sportova čije se nazivlje obrađivalo i sistematiziralo $u$ analiziranim rječnicima bio je vrlo velik. Ta činjenica govori o brojnosti različitih sportskih aktivnosti u svijetu - od onih poznatih širokoj publici do onih čija raširenost na globalnoj razini nije velika, ali pridonosi ukupnoj slici o njihovoj nevjerojatnoj brojnosti i raznovrsnosti. Kao treće, čini se da je održavanje velikih svjetskih sportskih natjecanja moguć povod za objavljivanje višejezičnih sportskih rječnika, i to na ne-engleskome govornom području. Četvrto, najveći je broj višejezičnih i dvojezičnih rječnika bio objavljen na ne-engleskome govornom području, dok je na engleskome govornom području bio objavljen najveći broj jednojezičnih rječnika. Pritom je najviše iznenadio podatak da na njemu nije bio objavljen nijedan višejezični rječnik, a istodobno broj jednojezičnih rječnika objavljenih na ne-engleskome govornom području nije bio zanemariv. Nadalje, što se interakcije govornoga područja na kojemu je rječnik objavljen i predmetnoga potpodručja tiče, rječnici objavljeni na engleskome govornom području najčešće su obrađivali terminologiju koja se rabi u nekoliko predmetnih potpodručja, a zatim slijede oni u kojima je prikupljena terminologija pojedinih sportova. Rječnici objavljeni na ne-engleskome govornom području najčešće su se bavili terminologijom jednoga sporta, a zatim kombinacijom potpodručja. Na kraju, rječnici koji su obrađivali terminologiju više od jednoga predmetnog potpodručja najčešće su bili jednojezični, značajno rjeđe dvojezični, a najrjeđe višejezični, dok su se višejezični rječnici bavili terminologijom samo jednoga sporta.

Rezultati u ovome istraživanju mogu biti osnova za daljnje analize koje bi se mogle baviti i drugim temama vezanima za sportske rječnike, na primjer, analizom samih natuknica ili redoslijedom jezika na kojima su 
natuknice prikazane. Ovo bi istraživanje moglo potaknuti i istraživanja o uporabi rječnika na nastavi stranoga jezika struke, koja su vrlo rijetka.

\section{LITERATURA}

Antón, M. T. O. i Nistal, P. F. (2015) Expert knowledge representation in bilingual e-dictionaries: A case study. Cadernos de Tradução (Florianópolis online) 35 (1), 167-191. doi: 10.5007/2175-7968.2015v35n1p167

Araúz, P. L., Benítez, P. F. i Hernández, Ch. P. (2008) LSP dictionaries and their genuine purpose: A frame-based example from MARCOCOSTA. U Bernal, E. i DeCesaris, J. (ur.) Proceedings of the XIII. EURALEX International Congress. Barcelona: Instituto Universitario de Lingüística Aplicada, 997-1006.

Aslan, E. (2016) A study on the use of mobile dictionaries in vocabulary teaching. Journal of Language and Linguistic Studies 12 (1), 1-8.

Bergenholtz, H. (2012) Concepts for monofunctional accounting dictionaries. Terminology 18 (2), 243-263. doi: 10.1075/term.18.2.05ber

Bergenholtz, H. i Tarp, S. (ur.) (1995) Manual of specialised lexicography: The preparation of specialised dictionaries. Amsterdam: John Benjamins Publishing Company. doi: 10.1075/btl.12

Bergenholtz, H. i Nielsen, S. (2006) Subject-field components as integrated parts of LSP dictionaries. Terminology 12 (2), 281-303. doi: 10.1075/term.12.2.07ber

Bergenholtz, H. i Kaufmann, U. (2017) Terminography and lexicography: A critical survey of dictionaries from a single specialised field. Hermes - Journal of Language and Communication in Business 10 (18), 91-125. doi: 10.7146/hjlcb.v10i18.25413

Beyer, E. (ur.) (1987) Wörterbuch der Sportwissenschaft: Deutsch - Englisch - Französisch / Dictionary of sport science: German - English - French / Dictionnaire des sciences du sport: Allemand - Anglais Français. Schorndorf: Verlag Karl Hofmann.

Biel, Ł. (2008) Legal terminology in translation practice: Dictionaries, googling or discussion forums? SKASE Journal of Translation and Interpretation 3 (1), 22-38.

Bonanno, V. (1988) Dizionario dello sport e di medicina sportiva inglese-italiano, italiano-inglese. Editioni Mediterranee.

Croatia lacrosse. (2020) http://croatia-lacrosse.com/hr/dokumenti/ (8. 3. 2020.).

Cummings, P. (1949) The dictionary of sports. Michigan: A.S. Barns.

Dziemianko, A. (2010) Dictionary, lexicon, glossary, wordbook or thesaurus? The usefulness of OALDCE7 and OLT for choosing the right word. U Dykstra, A. i Schoonheim, T. (ur.) Proceedings of the 14th EURALEX International Congress, 6-10 July 2010. Afûk, Ljouwert: Fryske Akademy, 1082-1091. https://www.euralex.org/elx_proceedings/Euralex2010/ (8. 3. 2020.).

Eberhard, D. M., Simons, G. F. i Fennig, Ch. D. (ur.) (2020a) Ethnologue: Languages of the world (22nd edition). - What are the 200 most spoken languages? Dallas, Texas: SIL International. http://www.ethnologue.com/guides/ethnologue200 (8. 3. 2020.).

Eberhard, D. M., Simons, G. F. i Fennig, Ch. D. (ur.) (2020b) Ethnologue: Languages of the world (22nd edition). - What is the most spoken language? Dallas, Texas: SIL International. http:// www.ethnologue.com/guides/most-spoken-languages (8. 3. 2020.).

Echevarría, R. G. (1999). The pride of Havana: A history of Cuban baseball. New York: Oxford University Press.

Encyclopaedia Britannica (2020) Rounders. https://www.britannica.com/sports/rounders (8. 3. 2020.).

Fata, I. (2017) Specialised dictionaries for LSP learners in Hungarian theory and practice of lexicography. Hermes - Journal of Language and Communication in Business 26 (50), 61-67. doi: 10.7146/ hjlcb.v26i50.97800

Federation of International Bandy. (n. d.) FIB member nations. http://www.worldbandy.com/members/ (8. 3. 2020.).

Figueredo, J. S. (2003). Cuban baseball: A statistical history, 1878-1961. Jefferson, North Carolina i London: McFarland \& Co Inc. 
Flinz, C. (2011) The microstructure of online linguistics dictionaries: Obligatory and facultative elements. U Kosem, I. i Kosem, K. (ur.) Proceedings of eLex 2011, 10-12 November 2011. Ljubljana: Trojina, 83-88. http://elex2011.trojina.si/Vsebine/proceedings/eLex2011-10.pdf (8. 3. 2020.).

Fuertes-Olivera, P. A. (2011) Equivalent selection in specialized e-lexicography: A case study with Spanish accounting terms. Lexikos 21 (1), 95-119. doi: 10.5788/21-1-39

Fuertes-Olivera, P. A. i Nielsen, S. (2011) Online dictionaries for assisting translators of LSP texts: The accounting dictionaries. International Journal of Lexicography 25 (2), 191-215. doi:10.1093/ ijl/ecr034

Fuertes-Olivera, P. A. i Tarp, S. (2011) Lexicography for the third millennium: Cognitive-oriented specialised dictionaries for learners. Ibérica 21, 141-162.

Giulianotti, R. i Robertson, R. (2004) The globalization of football: a study in the glocalization of the 'serious life'. The British Journal of Sociology 55 (4), 545-568. doi: 10.1111/j.1468-4446.2004.00037.x

Grdinić, V. (2010) Građa za enciklopedijski rječnik hrvatskoga analitičkog nazivlja. Dio I. Načela i polazište. Kemija u industriji 59 (7-8), 355-366.

Gu, P. Y. (2003) Vocabulary learning in a second language: Person, task, context and strategies. TESL-EJ 7 (2). http://www.tesl-ej.org/ej26/a4.html (17. 5. 2019.).

Halonja, A. (2008) Nacrt za rječnik hrvatskoga računalnog žargona. Filologija 50, 13-37.

Hartmann, R. R. K. (2005) Pure or hybrid? The development of mixed dictionary genres. Facta Universitatis: Linguistics and Literature 3(2), 193-208.

Hartmann, R. R. K. i James, G. (1998) Dictionary of lexicography. London, New York: Routledge.

Hepp, F. (ur.) (1960) Hétnyelvü sportszótár - Angol, Német, Spanyol, Olasz, Francia, Magyar, Orosz: úszás, vízilabda. Sports dictionary in seven languages - English, Deutsch, Espańol, Français, Magyar, Русский: Swimming, waterpolo. Budapest: Terra.

Jelaska, Z., Cvikić, L. i Novak, J. (2001) Rječnici hrvatskoga kao stranoga jezika. Filologija 36-37, 235-246.

Karpinska, L. (2018) Development of Latvian-English-Latvian dictionaries of legal terms (1991-2017). Baltic Journal of English Language, Literature and Culture 8, 74-88. doi: 10.22364/ BJELLC.08.2018.05

Kunzmann-Müller, B. (2001) Dvojezična leksikografija i manji jezici: problemi teorije i prakse. Rasprave Instituta za hrvatski jezik i jezikoslovlje 27 (1), 161-175.

Laufer, B. i Hadar, L. L. (1997) Assessing the effectiveness of monolingual, bilingual and "bilingualized" dictionaries in the comprehension and production of new words. The Modern Language Journal 81 (2), 189-196. doi: 10.1111/j.1540-4781.1997.tb01174.x

Lew, R. (2004) Which dictionary for whom? Receptive use of bilingual, monolingual and semibilingual dictionaries by Polish learners of English. Poznań: Motivex.

Lew, R. (2015) Dictionaries and their users. U Hanks, P. i De Schryver, G.-M. (ur.) International handbook of modern lexis and lexicography. Berlin, Heidelberg: Springer Verlag, 1-9. doi: 10.1007/9783-642-45369-4_11-1

L'Homme, M.-C. i Leroyer, P. (2009) Combining the semantics of collocations with situation-driven search paths in specialized dictionaries. Terminology 5 (2), 258-283. doi: 10.1075/term.15.2.05lho

Lipoński, W. (2009) "Hey, ref! Go, milk the canaries!” On the distinctiveness of the language of sport. Sports language and linguistics - Special issue of Studies in Physical Culture and Tourism 16 (1), 19-36.

Mallon, B. i Heijmans, J. (2011) Historical dictionary of the Olympic Movement (4th edition). Lanham: Rowman \& Littlefield.

Marotti, B. (2009) Rječnik hrvatskoga filozofskoga nazivlja. Prilozi za istraživanje hrvatske filozofske baštine 35 (1-2), 123-180.

Medelyan, O., Witten, I. H., Divoli, A. i Broekstra, J. (2013) Automatic construction of lexicons, taxonomies, ontologies, and other knowledge structures. Wiley Interdisciplinary Reviews: Data Mining and Knowledge Discovery 3(4), 257-279. doi: 10.1002/widm.1097

Međunarodni olimpijski odbor. (2015) Olimpijska povelja. http://hms.hr/wp-content/uploads/2015/02/1.-Olimpijska_povelja_2015-1.pdf (17. 5. 2019.).

Mihaljević, M. (1986) O nazivima rječnik, leksikon, enciklopedija i enciklopedijski rječnik. Jezik 34 (2), 52-54. 
Mihaljević, M. (1988) O naslovima terminoloških priručnika. Jezik 36 (3), 87-89.

Mihaljević, M. (1993) Definicija naziva u terminološkim rječnicima. Rasprave: Časopis Instituta za hrvatski jezik i jezikoslovlje 19 (1), 259-271.

Mihaljević, M. (2001) Terminološki rječnik i norma (uputnice, odrednice i normativne napomene u terminološkom rječniku). Rasprave Instituta za hrvatski jezik i jezikoslovlje 27, 191-208.

Nielsen, S. i Fuertes-Olivera, P. A. (2013) Development in lexicography: From polyfunctional to monofunctional accounting dictionaries. Lexikos 23 (1), 323-347. doi: 10.5788/23-1-1218

Novilist.hr. (2019) Međunarodni petanque turnir okupio 28 ekipa. http://novilist.hr/Vijesti/Regija/ node_1589/Medunarodni-Petanque-turnir-okupio-28-ekipa (8. 3. 2020.).

O'Neill, J. E. (2009) Bilingual baseball dictionary - English-Spanish, Spanish-English. St. Cloud, MN: Sentinel Print.

Peters, P. i Fernández, T. (2013) The lexical needs of ESP students in a professional field. English for Specific Purposes 32 (4), 236-247. doi: 10.1016/j.esp.2013.05.002

Pietrowski, T. (1994) Problems in bilingual lexicography. Wrocław: Wydawnictwo Uniwersytetu Wrocławskiego.

Pisanelli, D. M., Gangemi, A., Battaglia, M. i Catenacci, C. (2004) Coping with medical polysemy in the semantic web: The role of ontologies. Studies in Health Technology and Informatics 107 (Pt1), 416-417. doi: 10.3233/978-1-60750-949-3-416

Room, A. (2010) Dictionary of sports and games. Jefferson i London: McFarland \& Company, Inc.

Schierholz, S. J. (2003) Fachlexikographie und Terminographie. Zeitschrift für Angewandte Linguistik 39, 5-28.

Schmitz, K.-D. (2006) Wörterbuch, Thesaurus, Terminologie, Ontologie. Was tragen Terminologiewissenschaft und Informationswissenschaft zur Wissensordnung bei? U Harms, I., Luckhardt, H.-D. i Giessen, H. W. (ur.) Beiträge zu Informationswissenschaft, Computerlinguistik, Bibliothekswesen und verwandten Fächern. Festschrift für Harald H. Zimmermann. München: K. G. Saur, 129-137.

Tarp, S. (2010) Functions of specialised learners' dictionaries. U Fuertes-Olivera, P. A. (ur.) Specialised dictionaries for learners. Berlin/New York: Walter de Gruyter GmbH \& Co. KG, 39-53. doi: 10.1515/9783110231335.0.17

Tarp, S. (2012) Specialised lexicography: 20 years in slow motion. Ibérica 24, 117-128.

Total Sportek (n. d.) 25 world's most popular sports (Ranked by 13 factors). https://www.totalsportek.com/most-popular-sports/ (8. 3. 2020.).

Ujlaki Šubić, Lj. (2010) Rječnik olimpijskih i paraolimpijskih športova: Englesko-francusko-hrvatski. Zagreb: Školska knjiga.

Worldatlas (2020a) The most popular sports in the world. https://www.worldatlas.com/articles/ what-are-the-most-popular-sports-in-the-world.html (8. 3. 2020.).

Worldatlas (2020b) The most widely used languages in Europe. https://www.worldatlas.com/articles/most-widely-used-languages-in-europe.html (8. 3. 2020.).

Yildirim, K. (2006) Fusballwörterbuch in 7 Sprachen (Kauderwelsch 203). Osnabrück: Reise-Know-How Verlag Peter Rump.

Zagórska, A. (2017) Macrostructures and microstructures of multilingual LSP dictionaries. Lingwistyka Stosowana 21 (1), 187-199, doi: 10.32612/uw.20804814.2017.1.pp.187-199 


\section{A QUANTITATIVE ANALYSIS OF SPORTS DICTIONARIES}

Terminological dictionaries are aimed at collecting and organizing the terms specific for a particular domain or field. The development of society, science and technology is accompanied by the development of domains (or fields), ultimately resulting in an increasing number of published terminological dictionaries of particular domains, including sport. Since sport is a social phenomenon whose key feature is its global character, the analysis in this paper has focused on parameters describing a set of characteristics of sports dictionaries. The term sports has been applied in its very broad sense, which covers both the sub-fields of actual sports and the sub-fields of sports sciences (anatomy, physiology, psychology, biomechanics) as well as the theory of training. The aim was to analyse the sample of 103 sports dictionaries in terms of several aspects: the year of publication, language (English-/non-English speaking) area in which a dictionary was published, type of dictionary (mono-, bi- and multilingual dictionaries), language of publication and the sub-field covered by a dictionary. The results pointed to certain trends in the relationships among the analysed parameters. One of the key but also expected trends was the one that the dictionaries published in the English-speaking area were dominantly monolingual, and in most cases they have dealt with the terminology used in several sub-fields, whereas the dictionaries published in the non-English speaking area were predominantly multi- and bilingual, and have most frequently collected the terminology of only one sport.

Keywords: dictionary, sport, sub-field, terminology. 